\title{
A busca pessoal no direito brasileiro: medida processual probatória ou medida de polícia preventiva? ${ }^{1}$
}

\author{
Frisks in Brazilian Law: a tool of criminal \\ investigation or preventive policing?
}

Gisela Aguiar Wanderley ${ }^{2}$

Professora voluntária de Direito Penal na Universidade de Brasília - Brasília/DF

gisela.aguiarw@gmail.com

lattes.cnpq.br/6289663500945324

orcid.org/0000-0002-1875-7656

\begin{abstract}
Resumo: A busca pessoal (coloquialmente denominada "baculejo", "geral" ou "dura") é praticada de modo rotineiro no âmbito do policiamento ostensivo, a partir de fundamentação preventiva. Não obstante, esse uso da busca pessoal carece de permissivo legal. A partir de análise da legislação e de revisão crítica da doutrina pertinente, objetiva-se demonstrar neste artigo que a prática da busca pessoal como instrumento de policiamento ostensivo-preventivo é desprovida de suporte legal e se insere em um contexto de deficitária racionalização dogmático-jurídica da medida. Sustenta-se que a busca pessoal pode ser de duas espécies no direito brasileiro: pode visar à obtenção de prova no processo penal (busca probatória, regida pelo art. 244 do (PP), ou à inibição de situação de dano ou perigo iminente (busca inibitória, amparada pelas causas de exclusão de ilicitude do estado de necessidade ou da legítima defesa, descritas nos arts. $24 \mathrm{e}$ 25 do (P). Nenhuma dessas hipóteses se confunde com a prática da
\end{abstract}

1 Este artigo é produto de adaptação de capítulo da dissertação de mestrado da autora, defendida no âmbito do Programa de Pós-Graduação em Direito da Universidade de Brasília, com fomento da CAPES.

2 Professora voluntária de Direito Penal na Universidade de Brasília - Brasília/DF. Mestra em Direito, Estado e Constituição pela Universidade de Brasília (UnB). Graduada em Direito pela Universidade de Brasília (UnB). Analista Judiciária no Tribunal de Justiça do Distrito Federal e dos Territórios (TJDFT). 
busca pessoal com função de prevenção geral, seja esta negativa ou positiva, a qual manifesta a função punitiva latente da busca e se qualifica como uma medida ilegal.

Palavras-chave: busca pessoal; abordagem policial; policiamento preventivo.

ABSTRACT: Brazilian policemen perform frisks (patdowns) routinely, which are comprehended as part of urban preventive policing. The high number of frisks daily performed is justified by its alleged importance to control crime and make police visible. Nevertheless, by examining legislation and legal studies, this paper aims to clarify that this way of practicing frisks in a preventive manner is illegal and relates to the lacking legal studies on the topic. It is stressed that frisks are legally regulated as a procedure of obtaining criminal evidence, which is conditioned to founded suspicion of possession of forbidden weapon or other objects or papers that constitute corpus delicti. Also, frisks may be performed in face of imminent danger, under justification defenses (necessity, self-defense or defense of others). Anyhow, frisks may not be performed as a routine procedure of criminal general prevention.

KEYWORDS: stop and frisk; patdown; preventive policing.

SumÁrıo: Introdução. 1. Busca: definição, espécies e hipóteses legais de cabimento. 2. Natureza jurídica e finalidades da busca: a instrumentalidade e a referibilidade. 3. A "fundada suspeita". 4. Desvirtuação da suspeita: da "fundada suspeita" (de posse de corpo de delito) à "atitude suspeita". 5. Desfuncionalização da busca pessoal: de medida processual probatória a medida de polícia preventiva. 6. A busca pessoal preventiva como infrapenalidade policial: da racionalidade inquisitorial à racionalidade disciplinar. 7. A função punitiva latente da busca pessoal: a necessidade de estrita delimitação da busca pessoal com função inibitória. Conclusão. Referências.

\section{INTRODUÇÃO}

A busca pessoal ("baculejo", "geral”, "dura") não raro é aclamada como um indispensável instrumento de prevenção à criminalidade 
nos espaços públicos urbanos. Por essa perspectiva, é executada como verdadeiro expediente de rotina do policiamento ostensivo. Admitem-se buscas "preventivas" e até coletivas, que podem ser equiparadas a verdadeiras devassas, "varreduras" exercidas em caráter geral com o propósito de inspecionar, vigiar e controlar a circulação pública. Tais intervenções implicam a interrupção da liberdade de locomoção, bem como a violação à privacidade dos abordados, entre os quais se verifica uma incidência massivamente desproporcional de jovens negros e pobres ${ }^{3}$.

Ante tal cenário, é importante compreender o tratamento conferido à busca pessoal no direito brasileiro, a fim de identificar os fundamentos dogmático-jurídicos para a prática dessa recorrente medida policial restritiva de direitos. Para tanto, é forçoso avaliar a definição, a natureza jurídica, as hipóteses de cabimento e as finalidades da busca pessoal tal como normatizada na legislação. Afinal, quais os fundamentos, requisitos e finalidades de uma busca pessoal legal? Qual sua natureza jurídica? Existe permissivo legal para a sua execução como medida de polícia ostensivo-preventiva? A resposta a tais perguntas é condição necessária para a concentração e o controle da busca pessoal (cf. HASSEMER, 1994), em contraposição à admissão da sua prática cotidiana com base no mero arbítrio policial.

Nesse rumo, sob o marco do garantismo ${ }^{4}$, objetiva-se demonstrar neste artigo que a prática da busca pessoal como instrumento de policiamento ostensivo-preventivo é desprovida de suporte legal e se

3 Cf. WANDERLEY, 2017. Tal conformação empírica tem sido diagnosticada em inúmeras pesquisas desenvolvidas, sobretudo, no âmbito das ciências sociais. Conquanto a perspectiva empírica não constitua o objeto do presente trabalho, trata-se de premissa indispensável ao estudo dogmático-jurídico ora proposto.

4 Como aponta Ferrajoli (2014, p. 785-791), o garantismo corresponde a um modelo de Estado legitimado, no plano formal, pelo princípio da legalidade que implica a subordinação do exercício dos poderes públicos a leis gerais e abstratas -, e, no plano substancial, pela incorporação limitadora dos poderes públicos, condicionados e vinculados à da garantia dos direitos fundamentais, sendo que o controle de validade dos atos estatais envolve ambas as dimensões (formal e substancial). Em tal modelo, vincula-se o exercício do poder não a critérios potestativos de justiça, dotados de natureza extrajurídica, mas sim a condições de validade vinculativas e limitativas orientadas à efetivação dos direitos fundamentais. 
insere em um contexto de deficitária racionalização dogmático-jurídica da medida. Para tanto, a partir de análise da legislação vigente e de revisão da doutrina pertinente, elucidam-se inicialmente a definição e as hipóteses de cabimento da busca pessoal. Em seguida, esclarece-se que a própria doutrina processual penal tem reproduzido uma leitura incompleta do permissivo legal da busca pessoal, o que permite, ao cabo, a desfuncionalização da medida: esta é praticada não como medida probatória (como determina a lei), mas como mecanismo de disciplinarização dos transeuntes dos espaços públicos. Assim, explicita-se que a medida não tem assumido a racionalidade inquisitorial formatada pela sua regulamentação legal, mas sim uma racionalidade disciplinar tendencialmente restritiva das liberdades individuais (cf. FOUCAULT, 2014).

Em contraposição a tal cenário, objetiva-se colaborar para o aprimoramento da análise dogmático-jurídica da medida e fornecer ao próprio aparato policial (e às suas instâncias de controle) diretrizes que permitam discernir buscas pessoais legais e ilegais. Ao cabo, destaca-se então que a busca pessoal pode visar à obtenção de prova no processo penal (busca probatória, regida pelo art. 244 do CPP), ou à inibição de situação de dano ou perigo iminente (busca inibitória, amparada pelas causas de exclusão de ilicitude do estado de necessidade ou da legítima defesa, descritas nos arts. 24 e 25 do CP). Nenhuma dessas hipóteses se confunde com a prática da busca pessoal com função de prevenção geral, seja esta negativa ou positiva, a qual manifesta a função punitiva latente da busca e se qualifica como uma medida ilegal.

\section{BuSCA: DEFINIÇÃO, ESPÉCIES E HIPÓTESES LEGAIS DE CABIMENTO}

Em um sentido material, entende-se busca como o ato de procurar, varejar, rastrear, tentar descobrir vestígios, coisas ou pessoas. Marinoni e Arenhart (2011, p. 239) ressaltam que a busca consiste na "forma assumida por diversos mecanismos judiciais de apreensão e remoção de bens e de pessoas, para diversas finalidades”, razão pela qual não há "uma medida de busca e apreensão, mas sim uma disciplina genérica para qualquer hipótese em que seja necessário localizar, apreender e remover bens ou pessoas no interesse de um processo de caráter civil”. 
No direito processual penal, reputa-se que a busca "não surge aleatória, indeterminada ou indeterminável, mas se vincula com o que importa para a originária persecução penal que ensejou a ordem de busca” (PITOMBO, 2005b, p. 109). Assim, é procedimento de rastreamento e procura de objetos ou pessoas relacionadas ao fato aparentemente punível a que se refere o processo penal (ao caso penal ${ }^{5}$ ). É oportuna a remissão à definição de Pitombo (2005b, p. 109):

Ato do procedimento persecutivo penal, restritivo de direito individual (inviolabilidade da intimidade, vida privada, domicílio e da integridade física ou moral), consistente em procura, que pode ostentar-se na revista ou varejamento, conforme a hipótese: de pessoa (vítima de crime, suspeito, indiciado, acusado, condenado, testemunha e perito), semoventes, coisas (objetos, papéis e documentos), bem como de vestígios (rastros, sinais e pistas) da infração.

Nesse passo, a busca constitui um procedimento (forma) orientado a localizar vestígios, objetos ou pessoas no interesse de um processo penal. No Código de Processo Penal (CPP), a busca se subdivide em domiciliar e pessoal e é tratada conjuntamente com a apreensão (artigos 240 a 250), no Capítulo XI (Da Busca e da Apreensão) do Título VII do Livro I. Contudo, a doutrina comumente ressalva que a busca e a apreensão configuram institutos autônomos, mesmo que a apreensão seja a finalidade da busca (cf. MISSAGGIA, 2002, p. 201; LOPES JÚNIOR, 2012, p. 717; BARROS, R., 1982, p. 397; MARCÃO, 2014, p. 568).

A busca domiciliar é aquela realizada na casa, objeto de proteção constitucional como asilo inviolável do indivíduo (CF/88, art. 5ª $\mathrm{XI})^{6}$. A busca pessoal, por sua vez, é definida de modo residual como a revista realizada "na própria pessoa ou na esfera de custódia de que o acompanha” (MISSAGGIA, 2002, p. 202), o que abrange o corpo, as rou-

5 Entende-se "caso penal" aqui como o elemento objetivo da pretensão acusatória. Trata-se, pois, do fato aparentemente punível em relação ao qual se desenvolve a persecução penal. Cf. LOPES JÚNIOR, 2012, p. 157-158.

6 O conceito de casa abarca qualquer compartimento de habitação individual/ coletiva ou compartimento não aberto ao público onde alguém exerce profissão/atividade (CPP, art. 246, CP, art. 150, § $4^{\circ}$ ). 
pas e os pertences do indivíduo, aí incluído eventual veículo automotor (que não se destine à habitação). Assim, no Código de Processo Penal Militar (CPPM), a busca pessoal é definida como a "procura material feita nas vestes, pastas, malas e outros objetos que estejam com a pessoa revistada e, quando necessário, no próprio corpo" (art. 180).

As hipóteses de cabimento da busca domiciliar são delimitadas pelas possíveis finalidades da medida, as quais estão elencadas nas oito alíneas ("a” a "h") do $\S 1^{\circ}$ do artigo 240 do $\mathrm{CPP}^{7}$. Quanto à busca pessoal, de acordo com o $\S 2^{\circ}$ do mesmo artigo 240 do CPP, pode ser realizada quando houver fundada suspeita de que a pessoa oculta consigo arma proibida ou objeto mencionado nas alíneas " $b$ " a " $f$ " $e$ " $h$ " do $\S 1^{0}$.

$\mathrm{O}$ art. 244, por sua vez, prevê que a busca pessoal independerá de mandado prévio se for determinada incidentalmente no curso de prisão ou de busca domiciliar, ou, ainda, se houver fundada suspeita de que a pessoa esteja na posse de arma proibida ou de objetos ou papéis que constituam corpo de delito ${ }^{8}$. Esta última (busca pessoal sem mandado prévio e não incidental a outra medida) é a hipótese mais recorrente e também a mais polêmica, razão pela qual sobre ela recairá com maior concentração o presente estudo.

\section{Natureza JURÍDICA E FINALIDADES DA BUSCA: A INSTRUMENTALIDADE E A REFERIBILIDADE}

A definição de busca como um procedimento de procura e localização de pessoas, objetos ou vestígios no interesse de um processo penal permite classificá-la como um ato processual $^{9}$. Na Exposição de Motivos do CPP (item VII), de modo mais específico, estabelece-se que

7 Não há alteração substancial nas hipóteses de cabimento medida no Projeto de Novo CPP (PL n. 8.045/2010).

8 Há também permissivo legal para a prática da busca pessoal no Código de Processo Penal Militar (CPPM), nos arts. 180 a 182. Contudo, possui aplicação limitada à suspeita da prática de infrações penais militares, tema dotado de particularidade que foge ao objeto deste trabalho, razão pela qual não será objeto de análise pormenorizada.

9 "É toda ação humana que produza efeito jurídico em relação ao processo" (THEODORO JÚNIOR, 2011, p. 227). 
a busca constitui um expediente de consecução da prova. Ademais, sua regulamentação está inserida no Título VII (Da Prova) do Título I (Do Processo em Geral) do CPP.

Nesse sentido, a doutrina dominante frisa que a busca é uma medida instrutória, voltada à obtenção ou à preservação de provas para o processo penal, e parcela considerável acrescenta tratar-se de medida instrutória cautelar (MARQUES,, 2000, p. 379; ARANHA, 1999, p. 246; NORONHA, 1983, p. 92; OLIVEIRA, E., 2011, p. 442, LIMA, R., 2013, p. 701; MARCÃO, 2014, p. 569; CAPEZ, 2012, p. 362; DEMERCYAN; MALULY, 2014, p. 366; BONFIM, 2012, p. 381; TÁVORA; ALENCAR, 2012, p. 464; MACHADO, 2013, p. 717; LOPES JR., 2012, p. 717) ${ }^{10}$.

Feitos tais esclarecimentos, cabe notar que as possíveis finalidades da busca são marcadas por duas características essenciais: a referibilidade ao caso penal sob apuração e a instrumentalidade em relação à correlata persecução penal. Deveras, a busca constitui uma medida instrumental, que não visa ela própria a satisfazer nem a pretensão acusatória (objeto do processo penal), nem a pretensão punitiva (cujo exercício depende do prévio processo penal), mas apenas a viabilizar a efetividade da sua tutela, sem satisfazê-las diretamente ${ }^{11}$.

Noutro giro, a busca constitui uma medida referível ao caso penal, pois, ao visar a assegurar o exercício de uma tutela referente a determinado fato aparentemente punível, guarda com este uma relação de referibilidade. O caso penal constitui, pois, a causa de pedir remota

10 Há outra corrente doutrinária que sustenta que a busca é uma medida instrumental orientada à consecução de múltiplas finalidades e não apenas à obtenção/preservação da prova (COSTA, 1966, p. 100; MISSAGGIA, 2002, p. 200; RAMOS, 1998, p. 272; TORNAGHI, 1997, p. 476-477). Pondera-se que a busca pode constituir medida instrutória, mas também, a depender da sua finalidade, pode constituir medida cautelar patrimonial ou pessoal, como nos casos em que visar à efetivação de arresto/sequestro de bens (sem relevância probatória) ou ao próprio cumprimento de mandado de prisão do imputado (BARROS, R., 1982, p. 394; LIMA, M., 2014, p. 629; PITOMBO, 2005b, p. 116; NUCCI, 2012, p. 546). De todo modo, a busca pessoal regida pelo art. 244, objeto principal deste artigo, é dotada de finalidade probatória, conforme esclarecido a seguir.

11 Sobre o tema, cf. Zavascki (2009), que reanalisa a classificação das cautelares de Calamandrei a partir da distinção entre tutela cautelar e tutela antecipada e conclui pela existência de dois tipos de tutela cautelar: a tutela cautelar voltada à certificação do direito e a tutela cautelar voltada à execução do direito certificado. 
da busca ${ }^{12}$. Por isso, ao tratar da busca pessoal, Pitombo acentua que, a despeito da variedade de coisas que podem ser procuradas por meio da medida, "o importante é o relacionamento entre a coisa buscada e a infração penal” (2005b, p. 136).

A referibilidade e a instrumentalidade são características opostas à satisfatividade da tutela e traduzem a vinculação da busca ao processo penal. Tais características despontam da própria definição de busca, já que, como ressaltado, a busca é, no direito processual penal, definida como um ato de procura e localização de pessoas, objetos ou vestígios relacionados ao fato apurado no processo penal e no interesse do respectivo processo penal. Sobressaem em tal conceituação, de plano, a referibilidade ao caso penal e a instrumentalidade (direta ou indireta) em relação à tutela almejada no processo penal.

Portanto, o realce da referibilidade e da instrumentalidade permite elucidar que eventual busca sem relação com fato aparentemente punível e desatrelada da tutela almejada no processo penal não pode ser qualificada como uma busca processual penal e não possui fundamento no direito processual penal.

\section{A "FUNDADA SUSPEITA"}

Como o art. 244 do CPP requer a "fundada suspeita de que a pessoa esteja na posse de arma proibida ou de objetos ou papéis que cons-

12 A referibilidade consiste na relação de referência da tutela a uma situação material tutelável. A tutela assecuratória da certificação/cognição do direito ou da efetivação do direito exige referência, como causa de pedir remota, à relação jurídica material em que desponta tal direito: a tutela de segurança não visa a satisfazer esse direito, mas sempre faz referência a ele. A referibilidade da tutela cautelar, portanto, decorre da instrumentalidade, uma vez que funciona como tutela de segurança de outra tutela, daí decorrendo a necessária relação de referência daquela ao direito constitutivo do objeto desta (MARINONI; ARENHART, 2011). Assim, a tutela referível é concedida sempre no contexto de uma relação jurídica mais ampla, em razão da qual aquela se justifica, e que constitui sua causa de pedir remota. No processo penal, cujo objeto é a pretensão acusatória que tem por elemento objetivo o fato aparentemente punível, é sempre a pretensão acusatória relativa a determinado caso penal o objeto da referibilidade - o que contrasta com a variedade de pretensões tuteláveis pelo processo civil. 
tituam corpo de delito" para a execução da busca pessoal sem mandado prévio, a doutrina concentra suas ponderações relativas a esse dispositivo em torno da significação da expressão "fundada suspeita".

Alguns autores argumentam que tal expressão consubstancia uma exigência de cunho restritivo constante da própria lei, que deve então ser entendida como uma proibição legal de prática de buscas arbitrárias fundadas na mera intuição do policial (MARQUES, 2000, p. 378; TORNAGHI, 1997, p. 468; DEMERCIAN; MALULY, 2014, p. 368; TÁVORA; ALENCAR, 2012, p. 474; NUCCI, 2012, p. 552, 558-559). Portanto, destacam que a lei demanda um dado objetivo e concreto para a formação da suspeita: "[o] simples olhar do policial, entendendo tratar-se de um carro suspeito ou de uma pessoa suspeita, por exemplo, não pode autorizar a busca e apreensão" (RANGEL, 2014, p. 158).

Nesse passo, alerta-se que "a providência só restará autorizada diante de fundada suspeita, e não mera intuição ou capricho policial despido da necessária preocupação que se deve ter com a integridade das garantias fundamentais" (MARCÃO, 2014, p. 578). Entende-se então que "[n]ão satisfazem a exigência legal meras conjecturas ou impressões subjetivas (tino policial, por exemplo), mas elementos e circunstâncias concretas, objetivas, capazes e suficientes para motivar a conduta policial” (OLIVEIRA, A., 2014, p. 55).

Em sentido oposto, outros autores atribuem a dificuldade de definir a legalidade das buscas pessoais à larga amplitude da expressão "fundada suspeita". Há reiteradas manifestações doutrinárias no sentido de que a "fundada suspeita" é expressão demasiado ampla e dá margem a excessos e desvios autoritários (MEHMERI, 1996, p. 139; LOJES JR., 2012, p. 720; MACHADO, 2013, p. 720). Aduz-se que é “a permissão fornecida pela 'fundada suspeita' a causadora de arbitrariedades, porque é expressão extremamente genérica" (POLO, 2000, p. 9).

Assim, vê-se que o potencial exercício abusivo da busca pessoal pelas polícias não passa despercebido pela doutrina, pois a vasta maioria dos autores - até mesmo antes do advento da CF/88 (cf. NORONHA, 1983, p. 94-95; BARROS, R., 1982, p. 399; ANDRADE, I., 1958, p. 262; ESPÍNOLA FILHO, 1955, p. 197-202) - ressalta que a prática da medida implica a afetação de direitos fundamentais e por isso requer um fundamento objetivo que ultrapasse a mera intuição. 
As colocações doutrinárias, contudo, acabam se revelando desprovidas de efetividade quanto à alteração das rotinas policiais, nas quais a busca pessoal é realizada de modo generalizado e descontrolado. De um lado, a assertiva de que a exigência da "fundada suspeita" já constitui um empecilho ao arbítrio é lição restrita ao plano normativo, pois ignora o manejo cotidiano desse conceito pelas polícias de modo abertamente potestativo. De outro, a posição de que a "fundada suspeita” é demasiado vaga é desacompanhada de qualquer tentativa de conferir objetividade e concretude ao requisito, nem sequer via propostas de alteração legal.

Nesse cenário, identifica-se, de um lado, uma crença cega nos limites legais que são diariamente desobedecidos pelo aparato policial e, de outro, uma crítica à suposta vagueza da lei desatenta de seu próprio conteúdo e desatrelada de propostas concretas de superação do problema. Com isso, não se firmam parâmetros mínimos para o controle da atuação policial, de modo que a retórica doutrinária preocupada com os direitos fundamentais pode conviver com uma rotina de buscas pessoais arbitrárias e abusivas.

\section{Desvirtuação da suspeita: da "fundada suspeita" (DE posse de CORPO DE DELITO) À "ATITUDE SUSPEITA"}

Consoante abordado acima, é comum na doutrina processual penal a constatação de que a expressão "fundada suspeita" constante do art. 244 do CPP é demasiado vaga, ampla e genérica e, por isso, contrapõe-se ao caráter excepcional da busca pessoal e pouco contribui para o seu controle de validade. Desvios na prática da busca são então atribuídos à deficiência da lei. Outros autores, noutro extremo, argumentam que a "fundada suspeita" é um limitador da discricionariedade policial. Ignoram por completo, pois, o cenário atual de prática generalizada da busca pessoal como rotina do policiamento ostensivo.

No entanto, esses embates doutrinários, centrados em torno da expressão "fundada suspeita", amparam-se em uma leitura incompleta do art. 244 do CPP. Com efeito, esse dispositivo legal não exige mera "fundada suspeita”, genérica e indeterminável, para a prática de busca pessoal. Ao revés, o artigo 244 do CPP requer a fundada suspeita de 
que a pessoa esteja na posse de arma proibida ou de objetos ou papéis que constituam corpo de delito.

Portanto, a exigência de que a suspeita seja "fundada" delimita o grau de convencimento necessário para a busca pessoal: exige-se um juízo de probabilidade ${ }^{13}$ e não de certeza, o qual se refere, por sua vez, ao objeto da suspeita (posse de arma proibida/corpo de delito). Com efeito, não há como compreender a significação do adjetivo "fundada" sem correlacioná-lo ao objeto (complemento) da suspeita. Nenhum sentido faria admitir a prática da busca a partir de um juízo de probabilidade, sem indicar qual é o objeto de tal probabilidade. A noção de "fundada suspeita" não significa nada a menos que haja um objeto dessa suspeita.

A suspeita que justifica a busca pessoal se refere, pois, à posse de dois tipos de objetos pelo indivíduo: arma proibida ou outros objetos/papéis que constituam corpo de delito. No caso do porte de arma proibida, o objeto procurado já está delimitado pela própria norma, ao passo que, no caso de corpo de delito, é necessária, logicamente, a prévia delimitação da infração penal cujo corpo de delito estaria em posse do indivíduo. Não há como se suspeitar da posse de corpo de delito sem que antes se suspeite da prática de um delito, ao qual aquele se refere. Por conseguinte, a busca pessoal requer indícios de que foi praticada uma infração penal cujo corpo de delito (arma proibida ou outro objeto) ${ }^{14}$ está em posse do indivíduo.

13 A menção do art. 244 do CPP ao termo suspeita é acompanhada por um adjetivo antecedente ("fundada") e também por um complemento subsequente ("de que a pessoa esteja na posse de arma proibida ou de objetos ou papéis que constituam corpo de delito"). O adjetivo "fundado" é variante de "fundamentado", que significa "assentado em bases, razões, motivos sólidos" (HOUAISS; VILLAR, 2001, p. 1.404). Por outro lado, a "suspeita” (substantivo) é definida como a convicção "fundamentada em indícios, mas não provada, a respeito de algo ou de alguém" (HOUAISS; VILLAR, 2001, p. 2.648, sem grifos no original). Portanto, na própria definição de "suspeita", há a remissão à fundamentação em indícios relativos a um complemento. Assim, a "fundada suspeita" constitui uma convicção a respeito de algo ou alguém que, de modo destacado, está fundamentada em indícios que lhe confiram base sólida. Logo, com base no art. 239 do CPP, a busca pessoal requer a suspeita fundada em fatos ou circunstâncias certas, que autorizem, por indução, a conclusão de que a pessoa possui tais objetos.

14 Conforme se esclarecido na nota de rodapé n. 14, a arma proibida é uma espécie de corpo de delito. 
Não obstante, a dicção desse dispositivo legal é lida parcial e incompletamente pela própria doutrina processual penal, pois a "fundada suspeita de que a pessoa esteja na posse de arma proibida ou de objetos ou papéis que constituam corpo de delito" é reduzida à mera "fundada suspeita”, sem complemento. Assim, "é comum dizer-se que aquele que sofre a busca está sempre em atitude suspeita, em avaliação altamente subjetiva” (BARROS, A., 2007, p. 19). Com isso,

[o]pera-se, pois, um decote desautorizado dos objetos cuja fundada suspeita de posse justifica a busca pessoal. [...]. Verificase aí uma desvirtuação da suspeita, que perde a referibilidade a um complemento objetivo delimitado na lei e se torna um mero adjetivo, que pode ser atribuído pelo policial a quaisquer atitudes, pessoas ou situações, sem vinculação a qualquer delimitação legal - em especial, sem qualquer vinculação a infração penal legalmente tipificada. Como consequência, a suspeita, em vez de limitar as possibilidades de execução da busca pessoal, torna-se potestativamente manipulável pelo policial (WANDERLEY, 2017, p. 121).

A diferença entre a "fundada suspeita" de posse de arma proibida ou de corpo de delito, em relação à "atitude suspeita" (ou ao "indivíduo suspeito", à "situação suspeita”, entre outros) deve, então, ser enfatizada. A detecção de "atitudes suspeitas", em última instância, reduz-se a um juízo de mera adjetivação e, portanto, de mera opinião, o que o torna incontrolável. Pode-se argumentar, simplesmente: "às vezes uma coisa pode ser suspeita para mim, mas não pode ser suspeita para outra pessoa, vai depender do ponto de vista” (RAMOS; MUSUMECI, 2005, p. 37). Noutro giro, o juízo de subsunção da fundada suspeita de posse de arma proibida/corpo de delito exigida pelo art. 244 do CPP não se reduz a mera adjetivação. Na aplicação desse permissivo legal, não basta rotular atitudes, pessoas ou situações como suspeitas ${ }^{15}$. Deve-se indicar fatos

15 Como visto, a própria definição do substantivo "suspeita" já contém a remissão à fundamentação em indícios relativos a um complemento, que é enfatizada pelo adjetivo "fundada". Por outro lado, na definição do adjetivo "suspeito", está ausente a noção de "fundamento" e, também, está ausente a referência a um complemento, pois é definido apenas como aquele "que suscita inquietação ou cuidado” (HOUAISS; VILLAR, 2001, p. 2.648). Assim, 
que constituam indícios da posse de arma proibida/corpo de delito, em um juízo de subsunção normativa passível de revisão posterior por um terceiro independente e imparcial.

Nesse sentido, é interessante notar que, ao desvincular-se de condições jurídicas prévias e se amparar na mera rotulação do rótulo de suspeitas a determinadas pessoas, atitudes e situações, as buscas pessoais realizadas cotidianamente pelo aparato policial não constituem atos de imposição de regras, mas sim de criação de regras (cf. BECKER, 2008).

Com efeito, ao impor a regra do art. 244 do CPP, o policial deve indicar circunstâncias e fatos que indiquem que, no caso concreto, estão presentes indícios que configuram a fundada suspeita de posse de arma proibida ou de corpo de delito. Por outro lado, ao praticar busca pessoal embasada na mera adjetivação de atitudes como suspeitas, o policial não se limita a reconhecer a aplicabilidade do permissivo legal ao caso concreto, mas sim constrói ele próprio, com base em sua própria convicção, o permissivo para a busca. A saber, o policial rotula/ adjetiva pessoas, ações ou situações como suspeitas a partir de critérios por ele próprio formulados e que, de acordo com o seu juízo, permitiriam a busca. A busca pessoal se torna então um ato potestativo submetido a regras que podem ser criadas casuisticamente pelo próprio policial incumbido de impô-las.

Com isso, confere-se aos policiais não só o poder de selecionar as situações em que pode deixar de aplicar o permissivo legal de intervenção, mas também o poder de intervir a despeito da inexistência de permissivo legal. Não há aí mero juízo discricionário de aplicação seletiva da lei, mas sim a não-aplicação da lei, substituída por um juízo arbitrário do policial, feito em primeira e única instância, sobre a natureza "suspeita” das situações que justificariam sua própria intervenção. Por isso,

o adjetivo "suspeito" não possui a mesma carga semântica que o substantivo "suspeita", pois aquele se refere à mera fonte de inquietação, desprovida de embasamento em indícios. A mera leitura atenta das expressões já indica, portanto, que a equiparação da indicação de fundada suspeita (de posse de arma proibida ou de corpo de delito) à mera percepção de atitude/situação/ pessoa suspeita é caracterizada por um equívoco duplo: com a troca do substantivo (adjetivado e complementado) pelo mero adjetivo, de um lado, abandona-se a exigência de fundamentação em indícios e, de outro, abandona-se a referência ao complemento. 
Becker alerta que é possível encontrar "regras inventadas no momento unicamente para justificar o ato" e que algumas das "atividades informais e extralegais de policiais recaem nessa categoria” (2008, p. 140). Assim, não é casual a descrição da atuação da polícia como um "tribunal de rua" no que toca à busca pessoal (YUKA, 1999), já que, de fato, ao executá-la sem permissivo legal, o policial não só impõe a norma permissiva da coerção, mas cria essa própria norma, concentrando em si todo o poder de decisão.

Em tal contexto, a famigerada "atitude suspeita" (bem como o “indivíduo suspeito", a "situação suspeita” etc.), tão mencionada como o fundamento de buscas pessoais realizadas pelo aparato policial, deve ser desvelada como uma expressão atrelada a uma compreensão equivocada da aplicação do permissivo legal da busca pessoal. Tal expressão não se relaciona a um juízo de probabilidade da posse de corpo de delito ou arma proibida lastreado em indícios, mas sim a um juízo genérico de estranheza e (não) pertencimento do indivíduo em determinada conformação sócio espacial. A diferença entre os conceitos é evidenciada pela própria observação das estatísticas oficiais: se as "atitudes suspeitas" embasadoras das buscas realizadas fossem mesmo fundadas em indícios da posse de arma proibida/corpo de delito, o percentual de descoberta de crimes não se reduziria a patamares tão baixos, não raro inferiores a $2 \%$ (cf. WANDERLEY, 2017).

Portanto, a "atitude suspeita" e até mesmo a expressão legal "fundada suspeita" aparecem nos discursos policiais como um fundamento para a execução de buscas pessoais, sem corresponder ao requisito exigido pela lei, mas dando aparência de legalidade a tais medidas. Essa tática tem sido bem-sucedida, pois o discurso policial, embora vago e lacunar, tem sido rotineiramente chancelado pelas agências judiciais, que referendam a prática de buscas amparadas na percepção de "atitudes suspeitas" que não raro nem sequer são concretamente descritas pelos policiais (cf. SILVA, 2009, p. 78 e ss.). Nessa dinâmica, a referência genérica à suspeita funciona como um mecanismo automático de validação das escolhas policiais e, concomitantemente, como um mecanismo de afastamento da responsabilidade judicial pela seletividade das práticas policiais, já que a adjetivação de atitudes, indivíduos e situações como suspeitas se submeteria a critérios impassíveis de revisão judicial. 
Portanto, é só a partir do abandono do complemento da "fundada suspeita" exigida pelo art. 244 do CPP (posse de arma proibida ou corpo de delito) que pode ser esboçada alguma aproximação entre o juízo de subsunção normativa amparado nesse dispositivo legal e os juízos de adjetivação potestativa de lugares, situações, atitudes e pessoas como suspeitas a partir da "experiência de rua" pelos policiais. E, igualmente, é só a partir dessa leitura incompleta do art. 244 que se pode consolidar a orientação doutrinária no sentido de que a regulamentação legal da busca pessoal é vaga, imprecisa e deficiente. Cumpre então notar que "não apenas as normas penais se ressentem de linguagem vaga e/ou ambígua e fluidez de limites incriminadores e o ordenamento jurídico de contradições internas, mas também o instrumental dogmático que a elas se superpõe se ressente das mesmas características" (ANDRADE, V., 2003, p. 273).

Por isso, em contraposição ao atual cenário, é imprescindível insistir na leitura completa do art. 244 do CPP, o qual exige uma condição estrita para a busca pessoal sem mandado prévio. A lei não é vaga e indefinida nesse particular. Assim, não é preciso muito esforço hermenêutico para concluir que é ilegal a prática de buscas pessoais com base em genérica "atitude suspeita" de determinado indivíduo reputado destoante em determinado contexto socioespacial.

\section{DesfuncionalizaÇão da BUSCA PESSOAL: DE MEDIDA PROCESSUAL PROBATÓRIA A MEDIDA DE POLÍCIA PREVENTIVA}

De acordo com o art. 244 do CPP, a busca pessoal sem mandado prévio - salvo nas hipóteses em que for meramente incidental a busca domiciliar ou a prisão - tem uma finalidade delimitada: a apreensão de arma proibida ou de objetos e papéis constitutivos de corpo de delito ${ }^{16}$. Trata-se de objetos com valor probatório. Portanto, nesses casos, a busca pessoal tem sempre natureza jurídica de medida probatória/instrutória (meio de obtenção de prova).

16 Quanto ao corpo de delito, trata-se do "conjunto dos vestígios materiais deixados pelo crime” (TOURINHO FILHO, 2012, p. 293). Por outro lado, quanto à arma proibida, conceitua-se arma como o "artefato que tem por objetivo causar dano, permanente ou não, a seres vivos e coisas”. A arma proibida 
Extrai-se daí que o art. 244 do CPP não autoriza buscas pessoais com finalidade preventiva. Buscas orientadas à intimidação de criminosos em potencial, à garantia da sensação de segurança, à afirmação da presença policial, entre outros propósitos de matiz preventivo, não estão contemplados pelo art. 244. A execução de buscas com tais propósitos reflete a intolerável "desfuncionalização" da medida, utilizada "de modo cênico" no curso do policiamento ostensivo (PITOMBO, 2005a, p. 3). De fato, há desfuncionalização e, portanto, em ilegalidade, em todos esses casos em que se insiste em praticá-la com objetivos de prevenção geral.

Por outro lado, a exegese corriqueira do art. 244 do CPP, que reduz o requisito da busca pessoal à mera fundada suspeita (desprovida de complemento), impede a identificação das finalidades da medida, já que a "fundada suspeita" pode fazer referência a qualquer complemento. Assim, a leitura incompleta do art. 244 do CPP permite sustentar que haveria duas espécies de busca pessoal: a processual (instrutória) e a preventiva (cf. NASSARO, 2003, p. 46-56; CHOUKR, 2014, p. 509-511; RAMOS, 1998, p. 277-298; LIMA, M., 2014, p. 630):

No primeiro caso, a busca pessoal estaria vinculada a uma finalidade probatória e dependeria de indícios da posse do elemento probatório procurado (condição limitativa). Trata-se da hipótese prevista no art. 244 do CPP. No segundo caso, a busca pessoal poderia ser praticada com uma finalidade preventiva ampla e dependeria da mera rotulação de pessoa ou atitude como suspeita pelo policial (condição potestativa). [...] Assim, passa-se a admitir a sua prática em face de quaisquer "atitudes suspeitas", mesmo que desprovidas de vinculação com conduta delitiva. (WANDERLEY, 2017, p. 122-123).

constitui espécie de corpo de delito: a posse e o porte de arma de fogo são crimes de acordo com a Lei n. 10.826/03 (artigos 12, 14 e 16), que, por sua vez, é regulamentada pelo Decreto n. 5.123/04, que define os conceitos de arma de fogo de uso permitido (art. 10) e uso restrito (art. 11). De outra parte, a Lei de Contravenções Penais (LCP) tipifica como contravenção a conduta de portar arma, fora de casa, sem licença da autoridade (art. 19). Porém, vale pontuar que, na seara doutrinária e jurisprudencial, é controversa a aplicabilidade, a extensão e a constitucionalidade desse tipo penal. 
Portanto, a leitura incompleta do art. 244 do CPP é correlata à admissão do desvio de finalidade (desfuncionalização) da busca pessoal, que se transmuda de medida probatória em medida policial preventiva ${ }^{17}$.

$\mathrm{O}$ art. 244 do CPP, porém, não alberga qualquer possibilidade de busca meramente preventiva. Ao visar à apreensão de prova, pressupõe a prática pretérita ou atual de crime, o que exclui a possibilidade de a medida visar apenas à prevenção de possíveis crimes futuros. Nesse passo, tendo em mira que a busca processual penal é caracterizada pela instrumentalidade e pela referibilidade, Cleunice Pitombo adverte que a

17 Nesse sentido, Garcez Ramos argumenta que os artigos 240 a 250 do CPP poderiam ser erigidos como fundamento para a prática de busca como uma "providência preventiva de natureza policial": "[A] busca e apreensão é utilizável, no processo penal condenatório, como a) providência tendente à privação da liberdade do imputado, b) providência dirigida à proteção da atividade instrutória c) providência preventiva de natureza policial e, finalmente, d) medida preordenada à viabilização da responsabilidade civil decorrente do crime" (1998, p. 277). Para tanto, Ramos (1998, p. 298) ampara-se em especial na alínea "d" do $\S 1^{\circ}$ do art. 240 (busca para "apreender armas e munições, instrumentos utilizados na prática de crime ou destinados a fim delituoso"). Aduz que "é possível que não estejam ocorrendo sequer atos preparatórios de crime" e a busca funcionaria "como meio de execução de uma política estatal dirigida ao combate preventivo ao crime". No entanto, para dar sustentação empírica a tal hipótese, seria necessário que a busca ocorresse a partir de uma conjectura de que determinados objetos poderão ser utilizados para crimes futuros, sem que pudessem ter sido utilizados em crimes pretéritos ou atuais que pudessem justificar qualquer investigação. Por outro lado, além de tal dificuldade empírica, vale enfatizar que buscas sem instrumentalidade/referibilidade não apenas carecem de natureza cautelar (como reconhece Ramos), mas também carecem da própria natureza processual penal. Não há como afirmar que "a busca e apreensão é utilizável, no processo penal condenatório" (RAMOS, 1998, p. 277), com finalidades totalmente desvinculadas de tal "processo penal condenatório". Há aí contradição insuperável, assim como em Costa (1966, p. 100) e Marcellus Lima (2014, p. 630). Esclarece Marinoni que a tutela preventiva/inibitória não ostenta instrumentalidade e referibilidade em relação ao objeto do processo: "quando se teme um eventual ilícito, ou mesmo um eventual dano, a tutela que deve ser dirigida a impedir a sua produção é a inibitória" (2006, p. 209), a qual "tem por fim impedir a prática de um ilícito" (2008, p. 71). Por conseguinte, os arts. 240 e seguintes do CPP, que regem a busca como ato processual penal, não conferem autorização para "buscas preventivas". Interpretação em sentido contrário implicaria admitir a instrumentalização da legislação processual como pretexto para ações desprovidas de relação com o processo. 
busca pessoal, regulamentada nos artigos 240 , § $2^{\circ}$, e 244 do CPP, não se confunde com eventual busca movida por finalidade preventiva.

Contudo, a autora aduz que, embora a legislação processual penal não dê suporte a medidas meramente preventivas, a realização de revistas administrativas pela polícia estaria fundamentada no poder-dever de vigilância inerente aos órgãos policiais:

Não há que se confundir, porém, a diligência realizada pela polícia judiciária, ao praticar atos que poderão integrar o processo penal, revestida de todas as formalidades legais, com o poder-dever estatal de vigilância inerente aos órgãos de polícia (art. 144, § $4^{\circ}$, da Const. da República). A atividade preventiva exercida pela polícia, segundo Vicenzo Manzini, "não tem o escopo processual, nem de polícia judiciária, a 'perquisizione personali' feita de ofício e pelos agentes de segurança pública. Os fins desta atividade são de vigilância ou de segurança e não se destinam a procurar coisas relativas ao delito já cometido ou conhecido, ou ao menos suspeito". Assim, para garantir a paz pública, os órgãos da polícia podem efetuar busca administrativa, sem qualquer conotação processual. (2005b, p. 155)

Assim, embora a distinção entre "busca processual" (regida pelo CPP) e "busca preventiva" seja bem esclarecida pela autora, Pitombo (2005b, p. 155) limita-se a mencionar o artigo 144 da CF/88 como o fundamento normativo da "busca preventiva", que teria caráter administrativo. Esse posicionamento também é defendido, em especial, por autores com vínculo com as polícias militares. Assim, Nassaro (2003, p. 46-56; 2005), Amaral Neto (2009, p. 40-42) e Assis (2007, p. 5-11) defendem que a busca pessoal preventiva seria permitida pelo $\S 5^{\circ}$ do art. $144 \mathrm{da} \mathrm{CF} / 88$, o qual atribui às polícias militares estaduais a incumbência de preservação da ordem pública.

Porém, como o art. $144, \S 5^{\circ}$, do $\mathrm{CF} / 88$, que apenas atribui às polícias militares a incumbência de preservação da ordem pública, não regulamenta a prática de nenhum ato restritivo de direitos, tal como a busca pessoal, ele não prevê hipóteses de cabimento, finalidades, requisitos, modo de execução. Logo, não serve como permissivo para a sua execução.

A admissão da prática de buscas pessoais preventivas sem permissivo legal específico, com base em mera norma constitucional de 
repartição de atribuições, reflete uma orientação disciplinar do poder policial, que colide com o princípio da legalidade estrita - e em especial do postulado da nulla coatio sine lege. Admite-se o uso da coerção sem a submissão a qualquer vínculo ou condição legal, de maneira potestativa por parte das agências policiais. Com isso, ante o poderio policial ilimitado, as liberdades civis são inócuas, pois a polícia pode executar atos restritivos de tais liberdades, com função punitiva latente, sem nenhuma vinculação legal. Destaca-se daí, de fato, "um aspecto singular das opções políticas do uso da força no Brasil: a defesa da estratégia de generalizar a abordagem, independentemente das fundadas razões" (DUARTE et al., 2014, p. 98-99).

Portanto, é imprescindível notar que a disseminação de buscas generalizadas se alinha a "um padrão cultural muito difundido e incontestado que identifica a ordem e a autoridade ao uso da violência”, padrão esse ao qual é inerente a "deslegitimação dos direitos civis" (CALDEIRA, 2000, p. 136). De fato, só se poderia admitir a prática da busca pessoal, ato coercitivo e invasivo, sem autorização legal prévia e específica, em um sistema disciplinar (cf. FOUCAULT, 2008) ${ }^{18}$, compatível com o Estado de Polícia, em que todas as condutas são presumidamente proibidas e a fruição da liberdade é que exige permissão legal.

\section{A BUSCA PESSOAL PREVENTIVA COMO INFRAPENALIDADE POLICIAL: DA RACIONALIDADE INQUISITORIAL À RACIONALIDADE DISCIPLINAR}

Conforme aponta Foucault, as formas judiciárias correspondem a distintas formas de saber, vale dizer, a distintas configurações da relação entre o indivíduo e a verdade. Nesse sentido, o inquérito, for-

18 Tanto a legalidade quanto a disciplina são estruturados a partir de uma divisão binária entre proibido e permitido. No entanto, a lei determina o proibido, ao passo que a disciplina, ao revés, determina o permitido (FOUCAULT, 2008, p. 60): para a lei, o permitido é indeterminado (negativo), ao passo que, para a disciplina, o proibido é indeterminado (negativo). Sob a perspectiva da lei, "a ordem é o que resta quando se houver impedido de fato tudo o que é proibido" (FOUCAULT, 2008, p. 60-61). Por outro lado, a ordem disciplinar não diz o que é proibido, pois regula tudo e dita constantemente o que se pode-deve fazer: diz-se apenas o que é permitido - que, por sua vez, confunde-se com o 
ma de pesquisa e construção da verdade no interior da ordem jurídica que adquire proeminência nos séculos XV a XVIII, consiste em "um procedimento pelo qual, na prática judiciária, se procurava saber o que havia ocorrido" (2013, p. 88), a partir de um discurso retrospectivo ${ }^{19}$. Assim, as perguntas essenciais ao modelo inquisitorial referem-se ao que houve, quem fez, como fez: definem-se presença, ausência, existência, inexistência.

Essas são as perguntas que orientam os procedimentos de investigação e instrução processual penal. Nessa toada, a busca pessoal regida pelo art. 244 do CPP, como medida probatória, insere-se em uma racionalidade inquisitorial, já que visa a obter objeto que auxilie a reconstituição e comprovação de uma narrativa retrospectiva a respeito de um fato criminoso. O requisito da fundada suspeita de posse de arma proibida ou de corpo de delito é orientado exatamente pela probabilidade de encontrar objetos relevantes para a investigação/instrução. Por isso, reconhecida a busca pela verdade sobre fatos pretéritos como uma característica central do inquérito, pode-se vislumbrar a busca pessoal probatória como um ato por meio do qual se exerce um saber-poder que assume a forma inquisitorial ${ }^{20}$.

que é devido. Por isso, na ordem disciplinar, a liberdade é reduzida ao máximo e superada pelos imperativos de previsibilidade e controlabilidade.

Trata-se de forma de saber que nasce em função de transformações políticas que conferem centralidade ao Estado enquanto o lesado pela infração (e não mais à vítima diretamente atingida pelo dano), a partir da qual se visa a reatualizar um fato passado e a definir a culpabilidade do indivíduo em relação a um ato pretérito a partir de uma posição de pretensa neutralidade do sujeito de conhecimento diante do objeto (FOUCAULT, 2013, p. 134). É importante não confundir tal definição de inquérito, relacionado à investigação de fato pretérito, com a definição de inquérito ou de princípio inquisitório utilizada na dogmática processual penal para designar um procedimento marcado pela confusão entre o órgão de acusação e o órgão julgador e/ou entre suas funções), em contraste com o processo orientado pelo princípio acusatório, em que há uma nítida diferenciação entre acusador e juiz e também entre as funções desempenhadas por cada um. Sobre o tema, cf., por todos, LOPES JR., 2012, p. 115-126.

No tópico a seguir, apresenta-se a possibilidade da busca pessoal com função inibitória, caso em que é executada como um ato de coerção direta imediata e visa à apreensão de objeto lesivo (arma em sentido amplo) em poder do agente, independentemente de a posse do artefato constituir corpo de delito. Mesmo nesse caso, a intervenção se enquadra em situação excludente de ili- 
Não obstante, na prática do policiamento ostensivo, a realização de buscas pessoais orientadas à coibição de pessoas, atitudes e situações adjetivadas como suspeitas visa à consecução de finalidades diversas daquelas atreladas aos objetivos de obtenção de provas relacionadas a um crime pretérito ou de interrupção de um processo lesivo atual. Em substituição, objetivos genéricos do policiamento ostensivo assumem destaque, tais como a preservação da ordem, a prevenção geral de crimes, a afirmação da autoridade policial e a intimidação de potenciais criminosos. Tais objetivos dão ensejo a buscas pautadas por uma racionalidade distinta, conformada por outras formas de produção da verdade.

Deveras, no curso do policiamento ostensivo, não interessa unicamente aferir se determinados fatos ocorreram, mas também o que, em dado contexto ou ambiente, pode ou não ser feito para prevenir fatos futuros, ainda que desprovidos de nexo com fatos concretos pretéritos ou presentes. A esse respeito, Foucault (2013, p. 81-101) ressalta que, a partir de fins do século XVIII, na França e na Inglaterra, foram desenvolvidos mecanismos de controle permanente da população e do comportamento dos indivíduos de determinados grupos, voltados a manter a ordem. Foram criadas técnicas de controle da moralidade cotidiana, orientados a corrigir os indivíduos em seus comportamentos. Essas práticas de controle fizeram nascer um novo saber da individualidade, que classifica o sujeito conforme o binômio normal-anormal: disseminam-se práticas por meio das quais esse sujeito é classificado, conformado, normalizado.

Assim, concomitantemente à reforma liberal do sistema jurídico, erige-se um sistema disciplinar de controle social em que a noção central é a periculosidade do agente, e não a sua culpabilidade por um ato determinado (FOUCAULT, 2015, p. 278-295). Nesse contexto, dian-

citude (estado de necessidade ou legítima defesa) e perguntas orientadas ao passado orientam a decisão pela execução do ato, embora a prática danosa adquira caráter atual/presente e não apenas pretérito. Quando se objetiva apreender objeto lesivo em posse do agente, há uma tentativa de interromper um processo lesivo já em curso, o qual remete a um fato pretérito/presente (acesso e porte ao objeto lesivo) que culmina na situação de dano/perigo iminente (utilização efetiva do objeto lesivo) a ser interrompida. Assim, mesmo nessa hipótese, a racionalidade inquisitorial orienta a intervenção policial. 
te da ascensão das técnicas de vigilância de controle e da produção de saberes pela via de uma nova forma de produção da verdade, o inquérito perde centralidade: já não interessa apenas reconstituir um acontecimento, mas também vigiar alguém de maneira ininterrupta e global, a fim de se controlar não o que se fez e é feito, mas o que se é e o que se pode fazer, pela disseminação de mecanismos de sanção, normalização e correção. Constrói-se, pois, um saber a respeito do sujeito, a fim de determinar a sua normalidade (sua conformidade às normas), bem como aquilo que, prospectivamente, ele pode fazer (sua periculosidade).

Essas novas relações de saber-poder não se desvinculam dos modos de pesquisa e construção da verdade, que assumem a forma do exame em contraposição ao inquérito:

O exame combina as técnicas da hierarquia que vigia e as da sanção que normaliza. É um controle que normaliza, uma vigilância que permite qualificar, classificar e punir. Estabelece sobre os indivíduos uma visibilidade através da qual eles são diferenciados e sancionados. É por isso que, em todos os dispositivos de disciplina, o exame é altamente ritualizado. Nele vêm-se reunir a cerimônia do poder e a forma da experiência, a demonstração da força e o estabelecimento da verdade. No coração dos processos de disciplina, ele manifesta a sujeição dos que são percebidos como objetos e a objetivação dos que se sujeitam. A superposição das relações e das de saber assume no exame todo o seu brilho visível (FOUCAULT, 2014, 181).

De outra parte, cabe destacar que o exame requer tornar visíveis os indivíduos perante o "insone olhar do poder": é o fato de ser visto sem cessar, de sempre poder ser visto, que mantém sujeitado o indivíduo disciplinar. O poder capta os indivíduos a partir de um mecanismo de objetivação e manifesta-se ao organizar os objetos do espaço. O poder disciplinar manifesta-se, portanto, pelo olhar, colocando os indivíduos como objetos da observação. O exame é, em contrapartida, a cerimônia dessa objetivação, dessa visibilidade inevitável (FOUCAULT, 2014, p. 183-184).

Nessa dinâmica, “[o] próprio sistema de classificação vale como recompensa ou punição” (FOUCAULT, 2014, p. 177-178). A intervenção disciplinar, então, não se restringe a apenas expiar ou reprimir, pois 
serve para diversas operações. Serve para diferenciar os indivíduos entre si em função da regra de conjunto, para medir e hierarquizar suas capacidades e sua "natureza", para fazer então funcionar a coação da conformidade e, enfim, traçar o limite que define a anormalidade. Portanto, os instrumentos de vigilância e controle não visam única e exclusivamente ao exame do indivíduo, pois já contêm em si uma função punitiva, o que permite compreendê-los também como infrapenalidades.

No ponto, Foucault relaciona as infrapenalidades à imposição de uma ordem que não se reduz às regras previstas explicitamente na lei, mas que se define também por processos empíricos, com base em uma regularidade de condutas constatável a partir da observação dos fatos e de sua repetição. Tais castigos disciplinares orientam-se então à redução dos desvios, assumem um caráter essencialmente corretivo, normalizante, e são da ordem do exercício, impõem-se repetida e cotidianamente, a partir de uma "insistência redobrada", o que permite a construção progressiva de uma determinada ordem (2014, p. 176-177). A ordem surge, pois, como a acumulação de saberes sobre os indivíduos e sobre os ambientes em que estes se inserem, cuja organização se dá pela afirmação cotidiana das normas a serem seguidas.

Apresentada tal conformação, pode-se observar que a prática regular e cotidiana da busca pessoal nos espaços públicos com finalidade de prevenção geral se alinha a tal conformação, pois ao ser executada de modo generalizado funciona precisamente como uma técnica de "esquadrinhamento geral" dos indivíduos, justificada pelo propósito de garantir a sensação de segurança e combater/prevenir o crime. Com efeito, ao se deslocar a busca pessoal do interior da persecução penal para o cotidiano do policiamento ostensivo, a partir de uma justificativa de prevenção geral, esse ato se despe da forma inquisitorial e passa a se relacionar à constituição de um saber-poder disciplinar, para o qual não importa tanto saber o que os indivíduos fizeram, fazem ou deixam de fazer, mas sim o que podem ou são capazes de fazer. Nessa dinâmica, não importa a tipificação das condutas na legislação, mas sim o amplo campo de condutas desviantes e anormais, que se revelam nos menores detalhes: cabe à polícia reagir diante de tudo aquilo "que lhe chamar a atenção", vale dizer, diante de toda e qualquer atitude suspeita, independentemente da sua vinculação com um possível crime. 
Portanto, como expediente de rotina do policiamento ostensivo-preventivo, a busca pessoal é exercida não com objetivo de reconstituir e elucidar fatos criminosos pretéritos ou atuais, mas antes como um procedimento (cerimônia) de afirmação da autoridade policial e de objetivação da visibilidade inevitável dos indivíduos perante o olhar policial. O policial, incumbido da vigilância ininterrupta sobre os espaços, deve estar sempre apto a manifestar-se e a interpelar aqueles que ostentarem o menor sinal de desvio, para cuja detecção o policial possui uma especial habilidade construída a partir de sua experiência, a partir de sua observação repetida e continuada dos fluxos urbanos e trejeitos individuais ("tirocínio").

Nessa dinâmica, a busca surge como um rito que visa à afirmação desse saber-poder policial construído e constituído pela experiência policial. Por meio da busca, ao mesmo tempo, a conformidade do indivíduo à norma é aferida e afirmada e a autoridade policial reafirmada: verifica-se a periculosidade do agente e ratifica-se regular e cotidianamente a ordem visada pelo aparato policial. Diante de uma conduta desviante ou estranha, cabe à polícia afirmar a suspeição da conduta e ratificar a sua presença e a consequente visibilidade do indivíduo vigiado: entende-se que, diante de uma conduta suspeita, o policial "tem que no mínimo se mostrar ali”, de modo que a busca pessoal se transforma em um ato expressivo da própria ostensividade policial e se erige como um ato de rotina, e não de exceção, apesar de ser reconhecido como constrangedor e humilhante. Daí o tão recorrente elogio à importância da prática do ato em si, encarado como expressão da visibilidade policial e gerador da segurança pública, independentemente de sua relevância para a persecução penal.

Nesse passo, a suspeição, como mero juízo de estranheza, a indicar um indício de não conformidade, é suficiente para desencadear a intervenção policial coercitiva imediata, a qual funciona como instrumento de exame e como infrapenalidade. Vale dizer, a mera suspeição se erige como um fundamento suficiente para a (infra)punibilidade. A concepção subjacente é a de que a menor suspeita despertada no policial deve conduzir à abordagem: o policial não deve levar dúvida para casa. Assim, as buscas são executadas como infrapenalidades e instrumentos de exame, e se constituem como atos paulatinos de rejeição simbólica e 
exclusão física dos suspeitos: "são humilhantes e pretendem isso; visam a fazer o rejeitado/excluído aceitar sua imperfeição e inferioridade social" (BAUMAN, 1999, p. 135).

Esse modelo de prática da busca pessoal como reação disciplinar a pequenos desvios extralegais, além de se distanciar da busca probatória regida pelo CPP, não se compatibiliza com um sistema de legalidade estrita, caracterizado pela permissividade de todas as condutas não-proibidas na ordem jurídica e pela não punibilidade de desvios não definidos na lei.

\section{A FUNÇÃo PUNITIVA LATENTE dA BUSCA PESSOAL: A NECESSIDADE DE ESTRITA DELIMITAÇÃO DA BUSCA PESSOAL COM FUNÇÃO INIBITÓRIA}

A busca pessoal é precipuamente caracterizada pela restrição à liberdade ambulatorial e à privacidade individual do indivíduo abordado pelo agente policial. Com efeito, pressupõe, em primeiro lugar, a interpelação coercitiva do indivíduo, o qual tem interrompida a sua liberdade de circulação, ainda que por breves instantes. E, em sua execução, é inevitável a violação à sua privacidade, já que terá suas vestes revistadas e seu corpo apalpado pela autoridade policial. Em virtude de tais restrições de direitos, a busca pessoal é caracterizada por uma função punitiva latente, daí a possibilidade de ser executada como infrapenalidade pelas agências policiais.

Por ser uma medida "eventualmente penal", a busca pessoal deve se inserir no "horizonte do direito penal e, por conseguinte, sua aplicação deve submeter-se ao controle das agências jurídicas" (ZAFFARONI, 2001, p. 103). Com efeito, dada a incidência da busca pessoal sobre indivíduos selecionados pelo rótulo da suspeição, compreendidos como potenciais criminosos a serem interrompidos e averiguados pelo aparato policial, é inevitável a regulamentação de tal ato pela ótica do direito processual penal, que, no marco do garantismo, serve à tutela dos suspeitos, acusados e condenados de vinganças arbitrárias e excessivas por parte do sistema punitivo (FERRAJOLI, 2014, p. 311-312).

O caráter eventualmente penal da busca pessoal exige a sua estrita funcionalização aos propósitos não-penais que afastam a sua carac- 
terização como uma penalidade exercida autônoma e ilegalmente pelas polícias. Nos tópicos precedentes, esclareceu-se que a busca pessoal é autorizada pelo CPP como uma medida processual com função probatória, ao passo que é ilegal a busca pessoal com função de prevenção geral (negativa ou positiva) - tal como quando orientada à tutela da sensação de segurança, à intimidação dos criminosos, à afirmação da presença policial, entre outras justificativas que comumente embasam a prática da busca pessoal pelas polícias militares ${ }^{21}$.

A busca pessoal com função de prevenção geral constitui manifestação de sua função punitiva latente. Com efeito, a prevenção geral negativa e a prevenção geral positiva funcionam, inclusive, como fundamentos justificacionistas da própria sanção penal, a qual se legitimaria de acordo com tais doutrinas para desestimular condutas criminosas a partir da imposição da pena em caráter exemplar (prevenção geral negativa) ou para afirmar a vigência da ordem jurídica e da autoridade estatal (prevenção geral positiva) (cf. FERRAJOLI, 2014).

Apesar de a prevenção geral não servir como justificativa para a busca pessoal, cumpre indagar, porém, se esta medida pode ser praticada com função inibitória em relação a um dano ou perigo concreto, atual ou iminente. Isso porque, em tese, é possível que uma busca pessoal

${ }^{21}$ O elemento definidor do poder policial (poder das polícias) - que distingue a atuação das agências policiais em relação à das demais agências estatais (não-policiais) - é a coercitividade direta, vale dizer: a possibilidade do uso da força (BITTNER, 2003, p. 19-20). Deveras, o poder policial (das polícias) diferencia-se das demais manifestações do poder de polícia - definido, em síntese, como a atividade estatal restritiva de direitos e liberdades em razão da tutela de interesses sociais ou coletivos - não tanto em função de seus motivos e finalidades, mas sim em função da possibilidade/capacidade do uso da força física (violência), mediante coerção direta. No desenho institucional brasileiro, as agências policiais, municiadas do poder de coerção direta, são incumbidas de inúmeras atribuições, elencadas nos incisos do artigo $144 \mathrm{da} \mathrm{CF} / 88$, as quais abarcam, em especial, atos de investigação criminal, orientados à apuração de infrações penais, e atos de preservação da ordem pública, que apresentam caráter multifacetado e variável. À polícia federal e às policias civis estaduais incumbe exercer as atividades de polícia judiciária e apuração de infrações penais, nos termos dos $\S \S 1^{\circ}$ e $4^{\circ}$ do art. $144 \mathrm{da} \mathrm{CF} / 88$. Às polícias militares estaduais incumbe exercer a polícia ostensiva e a preservação da ordem pública, nos termos do $\S 5^{\circ}$ do mesmo dispositivo constitucional. 
sirva à inibição ou à interrupção de um perigo concreto ou dano: como essa medida permite a apreensão de objetos em poder do indivíduo, pode servir à neutralização de uma ação lesiva atual ou iminente com o uso de objetos lesivos (armas em sentido amplo: objetos que possam provocar lesão à incolumidade de terceiros). Nesse caso, independentemente de haver indícios de que a conduta do indivíduo abordado é criminosa e punível, o policial pode (e deve) intervir para cessar a situação de dano ou perigo.

Quanto ao ponto, breve remissão a um precedente da Suprema Corte estadunidense permite elucidar que a busca pessoal pode, eventualmente, assumir finalidade inibitória. No caso Terry v. Ohio ${ }^{22}$ a Suprema Corte reconheceu que a polícia, além de poder realizar buscas com finalidade investigativa (searches), também pode realizar revistas com finalidade protetiva (frisks). Para realizar buscas investigativas, a polícia depende da configuração de causa provável (probable cause), a qual corresponde, em síntese, a fatos ou circunstâncias suficientes para garantir a um indivíduo de razoável cautela que um crime está sendo cometido $^{23}$. Por outro lado, para realizar revistas protetivas, a polícia depende da configuração de suspeita razoável de que o indivíduo está armado e representa um perigo atual para o policial ou para outros transeuntes. A frisk se orienta, portanto, não ao propósito de investigar a prática de infração penal, mas ao propósito de inibir a utilização lesiva de arma.

Além da remissão ao direito estadunidense, a distinção entre a busca pessoal probatória e a inibitória pode ser reforçada pela análise do art. $5^{\circ}$, XI, da $\mathrm{CF} / 88$, que autoriza a entrada forçada em domicílio em quatro situações: flagrante delito, prestação de socorro, desastre e quando houver autorização judicial. Nas três primeiras, a intervenção possui instrumentalidade inibitória: visa a interromper situação de dano ou perigo e, por isso, deve ser imediata. Na última, possui instrumenta-

22 Terry v. Ohio, 392 U.S. 1 (1968). Sobre o tema, ver WANDERLEY, 2017.

23 Brinegar v. United States 338 U.S. 160 (1948): "Existe causa provável se os fatos e circunstâncias conhecidos pelo policial, ou dos quais ele possui informação verossímil e confiável, são suficientes por si só para garantir a um homem de razoável cautela a crer que um crime está sendo cometido" (tradução livre). 
lidade processual e pode constituir ato de busca, relacionado a persecução penal ou a demanda civil, o que afasta a existência de dano/perigo a ser inibido e atrai a exigência de autorização judicial prévia e a vedação de execução no período noturno ${ }^{24}$.

Nesse passo, em caráter análogo, a busca pessoal pode servir à obtenção de elemento probatório (nos termos do art. 244 do CPP), mas também à inibição de uma situação de dano ou de perigo de dano (probabilidade de dano $)^{25}$, quando visar à apreensão de objeto lesivo que possa ser usado pelo indivíduo para provocar dano a terceiros.

A busca pessoal com função inibitória não possui permissivo legal específico. Porém, a proteção de bem jurídico em situação de dano ou perigo atual ou iminente (que é a finalidade que a caracteriza) se amolda às causas excludentes de ilicitude de estado de necessidade e da legítima defesa (descritas, respectivamente, nos arts. 24 e 25 do CP).

Pode-se notar, pois, que a busca pessoal com função inibitória caracteriza-se como um ato de coerção direta imediata. A esse respeito, Zaffaroni (2001, p. 102) ressalta que a coerção direta é aquela inter-

24 Portanto, nas três primeiras situações, a entrada forçada em domicílio visa precipuamente a impedir a concretização de um perigo ou dano iminente a algum bem juridicamente tutelado. Com efeito, tanto na hipótese de flagrante delito, desastre ou prestação de socorro, a configuração de uma situação de perigo concreto ou dano permite e exige a atuação imediata do agente público. Observe-se que, em especial no caso do flagrante delito, além de evitar o dano ou o perigo que comumente exsurgem da prática de conduta criminosa, inicia-se, também, subsequentemente, a investigação e demais atos de persecução penal, notadamente mediante a prisão do infrator, a apreensão de objetos relacionados ao fato e demais atos elencados no art. $6^{\circ}$ do CPP. No entanto, o fundamento para a dispensa de autorização judicial prévia não decorre de tal instrumentalidade processual eventual, mas sim da urgência que normalmente decorre da prática atual do delito (em flagrante). Nesse sentido, a busca domiciliar, cuja finalidade é processual, não se confunde com a entrada forçada em domicílio motivada por situação de dano ou perigo concreto atual ou iminente, a legitimar a intervenção imediata (NASSARO, 2005, p. 23-24).

Aqui, conceitua-se "perigo" como a "probabilidade de dano", vale dizer, como uma "situação de fato, objetiva" da qual desponte potencialidade concreta de dano, e não como mera "probabilidade de perigo", a qual corresponde à noção de "risco", que é o "atributo da conduta humana que pode ou não causar um perigo”. Esta última noção, contudo, embora seja mais precisamente conceituada como "risco", é mencionada, na dogmática penal, como "perigo abstrato", reservando-se a expressão "perigo concreto" para a primeira realidade (BOTTINI, 2013, p. 89). 
venção na pessoa ou em seus bens "empregada ante um iminente perigo de lesão, ou porque urge interromper uma que se acha em curso" e pode ser imediata (instantânea) ou de execução diferida ou prolongada. Assim, "a coerção direta instantânea ou imediata não é outra coisa senão o estado de necessidade ou a legítima defesa convertidos em dever jurídico para o funcionário público" (2001, p. 104).

Quanto ao ponto, é crucial notar que, a despeito do caráter geral dos arts. 24 e 25 do CP, é bastante restrita a possibilidade de busca pessoal inibitória, por sua própria conformação material. Como a busca pessoal é um ato que objetiva e permite a descoberta/apreensão de objetos em posse do indivíduo, a busca pessoal inibitória (voltada à interrupção/coibição de lesão ou perigo de lesão) é cabível nos casos em que há a suspeita de posse de objeto lesivo (arma) pelo indivíduo, com o qual se possa gerar dano ou perigo.

O ponto mais sensível na definição da busca pessoal inibitória é, portanto, a diferenciação dessa excepcional medida em relação à busca pessoal com função de prevenção geral, tendencialmente generalizada e incontrolável. A prática de buscas pessoais generalizadas com a finalidade de prevenção geral negativa (v.g. intimidação de "potenciais criminosos") ou de prevenção geral positiva (v.g. visibilização e afirmação da autoridade policial em "zonas de alta criminalidade") não se vincula a uma situação de dano ou perigo concreto atual ou iminente - e, assim, não encontra suporte nas estritas hipóteses excludentes de ilicitude listadas nos arts. 24 e 25 do CP. O propósito de intimidar e constranger, sem vinculação à neutralização de um dano ou perigo concreto, revela a função punitiva latente da busca pessoal, e não se confunde com a busca pessoal inibitória.

A esse respeito, Zaffaroni (2001, p. 106-107) esclarece que a coerção direta não se confunde com a prevenção geral negativa, esta articulada como função positiva da pena: "a prevenção geral negativa pretende funcionar ex post facto e referir-se a uma atividade futura que não se empreendeu nem tampouco se sabe se será empreendida; a coerção direta funciona in facto e se refere a uma atividade em vias de realização". A prevenção geral positiva, por sua vez, se relaciona à tutela da higidez da própria autoridade policial e da ordem jurídica, se desvinculando da tutela de bens jurídicos em situação de dano ou perigo. 
Assim, Zaffaroni (2001, p. 102) ressalta que a coerção direta "adquire caráter punitivo quando excede o necessário para neutralizar um perigo iminente ou interromper um processo lesivo em curso" e, por isso, constitui "aquela de mais complexa delimitação em relação à pena”. Deve-se rechaçar, então, a prática da busca pessoal como reação a mera suspeita de perigo ou perigo de perigo (perigo abstrato), o que serviria à sua desconcentração e à manifestação de sua função punitiva.

Além disso, alguns esclarecimentos ancilares quanto à busca inibitória merecem destaque. A função inibitória da busca pode estar presente mesmo se o porte da arma não for proibido, como requer o art. 244 do CPP. Assim, nos casos em que o policial estiver diante de agente que aparentemente porte a arma licitamente, mas que deva ser desarmado com o objetivo de inibir potencial conduta lesiva em determinado contexto, a busca pessoal não possuirá finalidade probatória, mas, ainda assim, possuirá finalidade inibitória. Por outro lado, nos casos em que houver, concomitantemente, a suspeita de porte de arma proibida e de sua potencial utilização contra terceiros, a busca pessoal assume caráter concomitantemente probatório e inibitório. Por exemplo, ante a suspeita de que um indivíduo acabou de praticar um roubo com emprego de arma de fogo, a busca e apreensão da arma em poder do abordado, após a prática do delito, servirá não só à sua investigação, mas também à proteção do policial e de eventuais terceiros: terá instrumentalidade probatória e inibitória.

Ademais, a extensão da busca pessoal deve ser delimitada pela sua estrita instrumentalidade probatória e/ou inibitória. Por exemplo, em uma hipótese de instrumentalidade probatória, se a busca pessoal é motivada pela fundada suspeita do porte de um aparelho celular que tenha sido furtado (res furtiva: corpo de delito do crime de furto), então a extensão da busca deverá se restringir à procura por tal aparelho celular. Não se justificaria, a pretexto de procurar tal celular, inspecionar os objetos armazenados na carteira do indivíduo revistado, na qual jamais poderia estar ocultada a res furtiva cujo porte motivou a revista. Igualmente, em um caso de finalidade inibitória, se a busca pessoal visa ao desarme do indivíduo, então deverá se restringir à procura por armas. Não se justificaria, a pretexto de procurar arma, inspecionar minuciosamente os bolsos das vestes do indivíduo, nos quais não poderia 
estar ocultada arma. A extensão da busca deve se restringir aos atos necessários para verificar/refutar a fundada suspeita que a embasou.

Em síntese, pois, a busca pessoal é autorizada pelo art. 244 do CPP como medida probatória. Contudo, pode atender, também, a função inibitória, quando, em situações excepcionais, servir à neutralização de dano ou perigo atual ou iminente, ante a suspeita de que o indivíduo a ser revistado porta arma (proibida ou não) e pode utilizá-la para agredir o policial ou terceiros. Neste caso, a busca pessoal tem função inibitória e tem sua ilicitude excluída em função do estado de necessidade (CP, art. 24) ou da legítima defesa (CP, art. 25), a depender do caso. Em ambos os casos, é preciso que sejam apresentados pelo policial os fundamentos pelos quais praticou a busca pessoal, a fim de que se possa aferir se os requisitos de cada uma estavam presentes, em um controle a posteriori do juízo de subsunção normativa feito pelo policial. Os fundamentos da busca são, pois, vinculantes quanto à sua extensão e viabilizam a concentração e a controlabilidade jurídica da medida

De todo modo, porém, nenhuma dessas duas hipóteses (busca pessoal probatória e inibitória) se confunde com a prática generalizada e potestativa da busca pessoal com função de prevenção geral, a qual configura infrapenalidade dotada de função punitiva.

\section{CONCLUSÃo}

É difundida no senso comum a noção de que qualquer indivíduo que transita pelo espaço público pode ser abordado e revistado pela polícia (por todos, cf. RAMOS; MUSUMECI, 2005, p. 17). Por outro lado, na doutrina própria jurídica, afirma-se que a busca pessoal depende apenas de "fundada suspeita", não raro equiparada, nos discursos policiais, à indicação de atitude, pessoa ou situação rotulada como suspeita.

Consoante esclarecido nesse artigo, a mera adjetivação de atitudes, pessoas e situações como suspeitas, a partir de um potestativo juízo de estranheza e não pertencimento formulado pelo próprio policial, não se confunde com o requisito exigido pelo art. 244 do CPP para a prática da busca pessoal sem mandado prévio (fundada suspeita de posse de arma proibida ou outro corpo de delito pelo indivíduo). 
A inobservância sistemática do requisito exigido pelo CPP na prática da busca pessoal pelas polícias é sintomática. De acordo com a Exposição de Motivos do CPP, que remonta a 1941, o "espírito do Código" erigia a eficiência da repressão penal a objetivo prioritário e colocava as garantias dos acusados no mesmo plano dos "favores" e "franquias" que lhes seriam alegadamente concedidos pela legislação processual penal anterior. Assim, a regulamentação da busca pessoal no já autoritário CPP tem sido desobedecida a pretexto de se garantir segurança nos espaços públicos. Verifica-se, pois, uma escalada eficientista que impõe uma dupla e terminativa neutralização à eficácia dos direitos e garantias fundamentais: o imperativo de repressão à criminalidade é erigido para flexibilizar ou até mesmo afastar a aplicabilidade de normas que, no entanto, já foram elaboradas a partir desse mesmo imperativo.

Cumpre apontar, pois, que o arbítrio recorrente na prática da busca pessoal se relaciona não tanto a uma deficiência insuperável da lei - ainda que esta possa ser aperfeiçoada -, mas sim à interpretação frouxa e desatenta a ela conferida pela própria doutrina jurídica, a qual encampa, por sua vez, um controle insuficiente da validade da medida. Portanto, a prática sistemática de buscas arbitrárias, justificadas como procedimento de rotina, não deve ser associada à deficiência da lei ou à discricionariedade na aplicação da lei (selective enforcement), mas sim à não-aplicação da lei e à correlata deficiência do controle de legalidade do ato.

Nesse cenário, em contraposição a tal conjuntura, é imperativo reivindicar a estrita observância dos requisitos legais da busca pessoal pelas polícias, bem como aprimorar os mecanismos de fiscalização, monitoramento e controle da medida. Tais providências exigem uma alteração de postura não só das próprias corporações policiais, mas também das instituições de controle da atividade policial e da própria doutrina jurídica, a fim de conferir maior segurança jurídica na demarcação das fronteiras de legalidade dessa intervenção policial.

Motivado por tal ensejo, este artigo esclareceu que, no que toca à natureza jurídica, há duas espécies de busca pessoal admitidas no atual ordenamento: a probatória e a inibitória. As condições de validade de uma e outra não se confundem. No primeiro caso, a prática da busca pessoal depende da indicação de indícios da posse de corpo de deli- 
to pelo indivíduo (busca probatória, regida pelo art. 244 do CPP). No segundo, a busca pessoal depende da indicação de indícios da posse de arma a ser empregada contra o policial ou terceiros, em situação de dano ou perigo atual ou iminente (busca inibitória, amparada nas causas de exclusão de ilicitude dos arts. 24 e 25 do CP). Em ambos os casos, a extensão da busca deve ser limitada pelo fundamento que motivou a sua execução, evitando desvios. Por outro lado, fora de tais duas hipóteses de cabimento, a execução da busca pessoal como medida policial de prevenção geral, em face de pessoas, atitudes e situações potestativamente adjetivadas como "suspeitas", é uma medida ilegal. Neste ato, manifesta-se a função punitiva latente da busca, inserida em uma orientação disciplinar quanto ao policiamento dos espaços públicos, a ser rechaçada pelo aparato de controle da atividade policial.

\section{REFERÊNCIAS}

AMARAL NETO, Silas Bordini do. Busca pessoal como estratégia de eficiência na prevenção criminal e medida de preservação da ordem pública. Justitia, v. 66, n. 200, 2009.

ANDRADE, Ivan Moraes de. Polícia Judiciária. Rio de Janeiro: Forense, 1958.

ANDRADE, Vera Regina Pereira de. A ilusão de segurança jurídica: do controle da violência à violência do controle penal. Porto Alegre: Livraria do Advogado, 2003.

ARANHA, Adalberto de Camargo. Da prova no Processo Penal. São Paulo: Saraiva, 1999.

ASSIS, José Wilson Gomes de. Operações tipo blitz e buscas pessoais coletivas: as ações preventivas da Polícia Militar e sua legalidade. Jus Militaris, p. 5-6, 2007.

BARROS, Antonio Milton de. Busca e apreensão no processo penal. Revista Jurídica da Universidade de Franca, 2007, v. 9, n. 16, 2007, p. 9-30.

BARROS, Romeu Pires de Campos. Processo penal cautelar. Rio de Janeiro: Forense, 1982.

BAUMAN, Zygmunt. Globalização: as consequências humanas. Rio de Janeiro: Zahar, 1999. 
BECKER, Howard. Outsiders: estudos de sociologia do desvio. Rio de Janeiro: Zahar, 2008.

BITTNER, Egon. Aspectos do trabalho policial. São Paulo: Editora da USP, 2003. BONFIM, Eugenio Mougenot. Curso de processo penal. São Paulo: Saraiva, 2012. BOTTINI, Pierpaolo Cruz. Crimes de perigo abstrato. São Paulo: Revista dos Tribunais, 2013.

CALDEIRA, Teresa Pires do Rio. Cidade de Muros: crime, segregação e cidadania em São Paulo. São Paulo: 34/Edusp, 2000.

CAPEZ, Fernando. Curso de processo penal. 19ª ed. São Paulo: Saraiva, 2012.

CHOUKR, Fauzi Hassan. Código de Processo Penal: comentários consolidados e crítica jurisprudencial. São Paulo: Saraiva, 2014.

COSTA, Alfredo Araújo Lopes da. Medidas preventivas. Medidas preparatórias medidas de conservação. $3^{\text {a }}$ ed. São Paulo: Sugestões Literárias, 1966.

DEMERCIAN, Pedro Henrique; MALULY, Jorge Assaf. Curso de processo penal. $9^{\text {a }}$ ed. Rio de Janeiro: Forense, 2014.

DUARTE, Evandro Charles Piza et al. Quem é o suspeito do crime de tráfico de drogas? Anotações sobre a dinâmica dos preconceitos raciais e sociais na definição das condutas de usuário e traficante pelos policiais militares nas cidades de Brasília, Curitiba e Salvador. In: LIMA, Cristiane do Socorro Loureiro et al. (Org.). Segurança Pública e Direitos Humanos. Pensando a Segurança Pública. Brasília: Ministério da Justiça, Secretaria Nacional de Segurança Pública, 2014. v. 5. p. 81-118.

ESPÍNOLA FILHO, Eduardo. Código de Processo Penal Brasileiro Anotado. Rio de Janeiro: Borsoi, 1955. v. 3.

FERRAJOLI, Luigi. Direito e Razão: teoria do garantismo penal. São Paulo: Revista dos Tribunais, 2014.

FOUCAULT, Michel. A verdade e as formas jurídicas. Rio de Janeiro: Nau, 2013.

FOUCAULT, Michel. Microfísica do poder. $2^{\text {a }}$ ed. Rio de Janeiro: Paz e Terra, 2015.

FOUCAULT, Michel. Segurança, território, população. São Paulo: Martins Fontes, 2008.

FOUCAULT, Michel. Vigiar e punir: nascimento da prisão. 42. ed. Petrópolis: Vozes, 2014. 
HASSEMER, Winfried. Segurança pública no Estado de Direito. Revista Brasileira de Ciências Criminais, v. 2, n. 5, p. 55-69, 1994.

HOUAISS, Antônio; VILLAR, Mauro de Salles. Dicionário Houaiss da Língua Portuguesa. Rio de Janeiro: Objetiva, 2001.

LIMA, Renato Brasileiro de. Curso de processo penal. Niterói: Impetus, 2013.

LIMA, Marcellus Polastri. Curso de processo penal. $8^{\mathrm{a}}$ ed. Brasília: Gazeta Jurídica, 2014.

LOPES JÚNIOR, Aury. Direito processual penal. 9ª ed. São Paulo: Saraiva, 2012.

MACHADO, Antônio Alberto. Curso de processo penal. São Paulo: Atlas, 2013.

MARCÃO, Renato. Curso de processo penal. São Paulo: Saraiva, 2014.

MARINONI, Luiz Guilherme. Antecipação da tutela. São Paulo: Revista dos Tribunais, 2008.

MARINONI, Luiz Guilherme. Tutela inibitória: individual e coletiva. São Paulo: Revista dos Tribunais, 2006.

MARQUES, José Frederico. Elementos de direito processual penal. Campinas: Millenium, 2000, v. 2.

MEHMERI, Adilson. Manual Universitário de Processo Penal. São Paulo: Saraiva, 1996.

NASSARO, Adilson Luís Franco. A busca pessoal preventiva e a busca pessoal processual. Revista Força Policial, n. 45, 2005.

NASSARO, Adilson Luís Franco. Busca pessoal. 2003. Monografia (Especialização em Direito Processual Penal) - Escola Paulista da Magistratura, São Paulo, 2003.

NORONHA, Edgard Magalhães. Curso de direito processual penal. São Paulo: Saraiva, 1983.

NUCCI, Guilherme de Souza. Código de Processo Penal comentado. São Paulo: RT, 2012.

OLIVEIRA, Alessandro José Fernandes De. Estudos avançados de direito aplicado à atividade policial. Rio de Janeiro: Lumen Juris, 2014.

OLIVEIRA, Eugenio Pacelli de. Curso de processo penal. Rio de Janeiro: Lumen Juris, 2011. 
PITOMBO, Cleunice Bastos. A desfuncionalização da busca e da apreensão. Boletim IBCCRIM, v. 13, n. 151, p. 2-3, 2005 a.

PITOMBO, Cleunice Bastos. Da busca e da apreensão no processo penal. São Paulo: Revista dos Tribunais, 2005b.

POLO, Giovana. Busca e apreensão pessoal e prova ilícita. Boletim IBCCRIM, v. 8, n. 92, p. 9, 2000.

RAMOS, Silvia; MUSUMECI, Leonarda. Elemento suspeito: abordagem policial e discriminação na cidade do Rio de Janeiro. Rio de Janeiro: Civilização Brasileira, 2005.

RANGEL, Paulo. Direito processual penal. São Paulo: Atlas, 2014.

SILVA, Gilmar Gomes da. A lógica da PMDF na construção do suspeito. 2009. Dissertação (Mestrado em Sociologia) - Universidade de Brasília, Brasília, 2009. TÁVORA, Nelson; ALENCAR, Rosmar Rodrigues. Curso de direito processual penal. $7^{\text {a }}$ ed. Salvador: Juspodivm, 2012.

TORNAGHI, Hélio. Curso de processo penal. São Paulo: Saraiva, 1997. v. 1.

TOURINHO FILHO, Fernando da Costa. Processo penal. São Paulo: Saraiva, 2012. v. 3.

WANDERLEY, Gisela Aguiar. Entre a lei processual e a praxe policial: características e consequências da desconcentração e do descontrole da busca pessoal. Revista Brasileira de Ciências Criminais, v. 128, n. 25, p. 115-149, 2017.

YUKA, Marcelo. Tribunal de Rua. In: RAPPA. Lado B Lado A. [S.1.]: Warner, 1999, CD, Fx 1.

ZAFFARONI, Eugenio Raul. Em busca das penas perdidas. Rio de Janeiro: Revan, 2001.

ZAVASCKI, Teori. Antecipação da tutela. São Paulo: Saraiva, 2009. 


\section{Informações adicionais e declarações dos autores (integridade científica)}

Declaração de conflito de interesses (conflict of interest declaration): a autora confirma que não há conflitos de interesse na realização das pesquisas expostas e na redação deste artigo.

Declaração de coautoria e especificação das contribuições (declaration of authorship): todas e somente as pessoas que atendem os requisitos de autoria deste artigo estão listadas como autores; a autora se responsabiliza integralmente por este trabalho em sua totalidade.

Declaração de ineditismo e originalidade (declaration of originality): a autora assegura que o texto aqui publicado não foi divulgado anteriormente em outro meio e que futura republicação somente se realizará com a indicação expressa da referência desta publicação original; também atesta que não há plágio de terceiros ou autoplágio. Este artigo é produto de adaptação de capítulo da dissertação de mestrado da autora, defendida no âmbito do Programa de Pós-Graduação em Direito da Universidade de Brasília, com fomento da CAPES.

\section{Dados do processo editorial}

(http://www.ibraspp.com.br/revista/index.php/RBDPP/about/editorialPolicies)

- Recebido em: 31/07/2017

- Controle preliminar e verificação de plágio: 07/06/2017

- Avaliação 1: 12/08/2017

- Avaliação 2: 15/08/2017

- Avaliação 3: 20/08/2017

- Decisão editorial preliminar: 24/08/2017

- Retorno rodada de correções: 04/09/2017

- Decisão editorial final: 04/09/2017

\section{Equipe editorial envolvida}

- Editor-chefe: 1 (VGV)

- Revisores: 3 


\section{COMO CITAR ESTE ARTIGO:}

WANDERLEY, Gisela Aguiar. A busca pessoal no direito brasileiro: medida processual probatória ou medida de polícia preventiva? Revista Brasileira de Direito Processual Penal, Porto Alegre, vol. 3, n. 3, p. 1117-1154, set./dez. 2017. https://doi.org/10.22197/rbdpp.v3i3.96

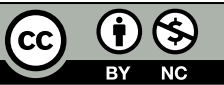

Esta obra está licenciada com uma Licença Creative Commons Atribuição-NãoComercial 4.0 Internacional. 